\title{
Evaluation of Digoxin Concentration after Loading Dose in Patients with Renal Dysfunction
}

\author{
Nadia Pawlosky, Erika MacDonald, Rakesh Patel, and Salmaan Kanji
}

\begin{abstract}
Background: Loading dose recommendations for digoxin are based on the volume of distribution, which is proportional to lean body weight, whereas maintenance dose recommendations depend on renal function. The volume of distribution of this drug is demonstrably reduced in severe renal dysfunction, but the threshold at which a reduction in loading dose is warranted remains unknown.
\end{abstract}

Objectives: To describe the practice of digoxin loading at The Ottawa Hospital and to determine the proportion of patients, categorized by degree of renal function, who experienced digoxin toxicity after a loading dose.

Methods: Data were collected retrospectively from charts of patients who had received a digoxin loading dose between May 2008 and January 2012, with a blood sample drawn for determination of digoxin concentration 6 to $24 \mathrm{~h}$ later. Patients were categorized into 4 groups according to creatinine clearance.

Results: The mean loading dose of digoxin ( \pm standard deviation) was $9.8 \pm 4.1 \mu \mathrm{g} / \mathrm{kg}$ among patients with creatinine clearance below 15 $\mathrm{mL} / \mathrm{min}, 14.4 \pm 5.4 \mu \mathrm{g} / \mathrm{kg}$ for those with creatinine clearance between 15 and $29 \mathrm{~mL} / \mathrm{min}, 16.0 \pm 5.6 \mu \mathrm{g} / \mathrm{kg}$ for those with creatinine clearance between 30 and $59 \mathrm{~mL} / \mathrm{min}$, and $14.0 \pm 3.7 \mu \mathrm{g} / \mathrm{kg}$ for those with creatinine clearance $60 \mathrm{~mL} / \mathrm{min}$ or above. Degree of renal dysfunction, particularly creatinine clearance below $60 \mathrm{~mL} / \mathrm{min}$, predicted the likelihood of experiencing a toxic serum concentration of digoxin after the loading dose, after adjustment for dose and weight (odds ratio 2.60, $95 \%$ confidence interval $1.55-4.39$ ).

Conclusions: Patients with creatinine clearance below $60 \mathrm{~mL} / \mathrm{min}$ were more likely than those with creatinine clearance of $60 \mathrm{~mL} / \mathrm{min}$ or greater to experience toxic serum digoxin concentrations with current loading dose strategies. It is recommended that loading doses be reduced (to $6-10 \mu \mathrm{g} / \mathrm{kg}$ ) for these patients. Prospective trials are required to determine the clinical implications of these findings and to determine if greater reductions in loading dose are required for patients with severe renal dysfunction (i.e., creatinine clearance below $30 \mathrm{~mL} / \mathrm{min}$ ).

Key words: digoxin, loading dose, renal dysfunction, drug monitoring

Can J Hosp Pharm 2013;66(2):104-109

\section{RÉSUMÉ}

Contexte : La dose d'attaque de digoxine recommandée est basée sur le volume de distribution, qui est proportionnel au poids maigre, alors que la dose d'entretien recommandée dépend de la fonction rénale. Il a été démontré que le volume de distribution de la digoxine était réduit en présence d'insuffisance rénale grave, mais on ignore à quel seuil une réduction de la dose d'attaque est justifiée.

Objectifs : Décrire la pratique en matière de dose d'attaque de la digoxine à l'Hôpital d'Ottawa et déterminer la proportion de patients, classés par degré de fonction rénale, qui ont éprouvé des effets toxiques de la digoxine après l'administration d'une dose d'attaque.

Méthodes : Les données ont été recueillies rétrospectivement à partir des dossiers des patients qui, entre mai 2008 et janvier 2012, avaient reçu une dose d'attaque de digoxine et fait l'objet d'un prélèvement sanguin afin de déterminer la concentration de digoxine de 6 à 24 heures après l'administration du médicament. Les patients ont été classés en quatre groupes selon la clairance de la créatinine.

Résultats : La dose d'attaque moyenne de digoxine ( \pm l'écart-type) était de $9,8 \pm 4,1 \mu \mathrm{g} / \mathrm{kg}$ chez les patients dont la clairance de la créatinine était inférieure à $15 \mathrm{~mL} / \mathrm{min}$, de $14,4 \pm 5,4 \mu \mathrm{g} / \mathrm{kg}$ chez ceux dont cette clairance s'établissait entre 15 et $29 \mathrm{~mL} / \mathrm{min}$, de $16,0 \pm 5,6 \mu \mathrm{g} / \mathrm{kg}$ chez ceux dont cette clairance s'établissait entre 30 et $59 \mathrm{~mL} / \mathrm{min}$ et de $14,0 \pm 3,7 \mu \mathrm{g} / \mathrm{kg}$ chez les patients dont la clairance de la créatinine était de $60 \mathrm{~mL} / \mathrm{min}$ ou plus. Le degré d'insuffisance rénale, particulièrement dans les cas de clairance de la créatinine inférieure à $60 \mathrm{~mL} / \mathrm{min}$, était prédictif d'une concentration sérique toxique de digoxine à la suite de la dose d'attaque, après ajustement en fonction de la dose et du poids (risque relatif approché de 2,60, intervalle de confiance à $95 \%: 1,55$ à 4,39).

Conclusions: Les patients dont la clairance de la créatinine était inférieure à $60 \mathrm{~mL} / \mathrm{min}$ étaient plus susceptibles de présenter des concentrations sériques toxiques de digoxine avec les stratégies actuelles d'établissement des doses d'attaque que les patients dont cette clairance était de $60 \mathrm{~mL} / \mathrm{min}$ ou plus. Il est recommandé de réduire les doses d'attaque (à 6 a $10 \mu \mathrm{g} / \mathrm{kg}$ ) chez ces patients. Des études prospectives sont nécessaires pour déterminer les répercussions cliniques de ces résultats et pour déterminer si des réductions plus importantes de la dose d'attaque sont requises chez les patients présentant une insuffisance rénale grave (c.-à-d. dont la clairance de la créatinine est inférieure à $30 \mathrm{~mL} / \mathrm{min}$ ).

Mots clés : digoxine, dose d'attaque, insuffisance rénale, suivi pharmacologique

[Traduction par l'éditeur] 


\section{INTRODUCTION}

$\mathrm{C}$ ontroversy exists concerning the appropriate loading dose of digoxin, a cardiac glycoside with negative chronotropic and positive inotropic effects that is used for atrial fibrillation and heart failure. The manufacturer recommends 8 to $12 \mu \mathrm{g} / \mathrm{kg}$ ideal body weight (based on projected peak body stores) in divided doses ( $50 \%$ of calculated dose initially, then 2 doses of $25 \%$ each at 6 - to 8 -h intervals), noting that the loading dose is frequently given by injection, with conversion to oral formulations for maintenance therapy. ${ }^{1}$ In their 2006 guidelines for the management of patients with atrial fibrillation, the American College of Cardiology, the American Heart Association, and the European Society of Cardiology recommended $0.25 \mathrm{mg}$ IV every $2 \mathrm{~h}$ (to a maximum of $1.5 \mathrm{mg}$ ) or $0.5 \mathrm{mg}$ orally daily, depending on the acuity of the patient's situation. ${ }^{2}$ The guidelines recommend IV administration when rapid control of ventricular response to atrial fibrillation is required; oral administration may be used for hemodynamically stable patients. ${ }^{2}$ At the authors' institution, a common practice has been to give a $1-\mathrm{mg}$ oral or IV loading dose $(0.5 \mathrm{mg}$ initially, then 2 doses of $0.25 \mathrm{mg}$ each every $6 \mathrm{~h}$ ).

To allow adequate time for equilibration of digoxin between serum and tissue, the manufacturer recommends that digoxin concentration be measured just before the next scheduled dose of the drug or at least $6-8 \mathrm{~h}$ after the last dose (regardless of route of administration). The concentration range historically selected as "therapeutic" is 1.0 to $2.6 \mathrm{nmol} / \mathrm{L}$. Approximately two-thirds of patients with clinical symptoms of digoxin toxicity have serum concentration greater than $2.6 \mathrm{nmol} / \mathrm{L}$; consequently, one-third of patients experiencing clinical symptoms of toxicity have concentrations less than $2.6 \mathrm{nmol} / \mathrm{L} .{ }^{1}$ At the authors' institution, the usual therapeutic range 6 to $8 \mathrm{~h}$ after completion of the loading dose is 1.0 to $2.6 \mathrm{nmol} / \mathrm{L} .{ }^{3}$

The available literature suggests that the loading dose of digoxin should be reduced for patients with renal dysfunction, because of a decreased volume of distribution for this drug in these patients. ${ }^{4.8}$ However, the recommendations are inconsistent with respect to the extent of dose reduction, as well as the degree of renal dysfunction that necessitates a reduction. The product monograph recommends decreasing the loading dose from $8-12 \mu \mathrm{g} / \mathrm{kg}$ to $6-10 \mu \mathrm{g} / \mathrm{kg}$ for patients with renal insufficiency but does not define insufficiency. ${ }^{1}$ At the authors' institution, the question of what digoxin loading dose to administer to patients with renal dysfunction often arises, and some patients with renal dysfunction receive the full loading dose.

The primary objectives of this study were to describe the current practice of digoxin loading at three tertiary care teaching centres (the Civic and General campuses of The Ottawa
Hospital and the affiliated University of Ottawa Heart Institute) and to determine, for patients with different degrees of renal function, the proportion who experienced a toxic serum concentration of digoxin after a loading dose. Secondary objectives were to determine the relationship between digoxin concentration after a loading dose and degree of renal function, to determine the degree of renal dysfunction at which there is an increased risk of post-loading dose digoxin toxicity, and to describe the frequency of symptomatic toxicity and administration of antidote. For the purposes of this study, serum concentrations above the therapeutic range $(1.0-2.6 \mathrm{nmol} / \mathrm{L})$ were designated as "toxic", and true toxicity is discussed as such.

\section{METHODS}

Approval was obtained from The Ottawa Hospital Research and Ethics Board for this retrospective observational study.

\section{Study Population}

The medical records of consecutive patients admitted to The Ottawa Hospital General or Civic campus or the University of Ottawa Heart Institute were screened backward, starting with discharges that occurred in January 2012, according to the following criteria, with pharmacy records being used to identify patients for whom any digoxin dose of at least $0.25 \mathrm{mg}$ was administered via any route. Patients were included if they were 18 years of age or older, had received a loading dose of digoxin (either IV or orally), and had not received digoxin within 2 weeks before the loading dose, and if blood for determination of serum digoxin concentration had been drawn within 6 to $24 \mathrm{~h}$ after administration of the last portion of the loading dose. Patients were excluded if body weight and height were both absent from the medical record, if body weight was above $120 \mathrm{~kg}$ (i.e., obese) and height was not available for calculation of ideal body weight, or if they had received any renal replacement therapy between the time of loading dose administration and the time the sample was drawn for determination of serum digoxin concentration.

\section{Data Collection and Analytical Plan}

Eligible patients were categorized into 1 of 4 groups according to degree of renal function, as estimated by creatinine clearance $(\mathrm{CrCl}): 60 \mathrm{~mL} / \mathrm{min}$ or above, 30 to $59 \mathrm{~mL} / \mathrm{min}, 15$ to $29 \mathrm{~mL} / \mathrm{min}$, and less than $15 \mathrm{~mL} / \mathrm{min}$. ${ }^{9,10}$ Enrolment within each category was capped at 50 consecutive patients, with a total target convenience sample of 200 patients. Data were collected retrospectively from each patient's medical record by a single investigator (N.P.), who used a standardized casereporting form. When both height and weight were available from the chart, the Cockcroft-Gault equation was used to 
estimate creatinine clearance on the basis of ideal body weight, unless actual body weight was less than ideal body weight. ${ }^{11}$ If only weight was available, actual body weight was used for the calculation, with exclusion of any patients documented as being obese (as noted above).

The following demographic and clinical data were collected: age, sex, weight, height, indication for treatment with digoxin, presence of concomitant therapies that could influence digoxin concentration or interfere with digoxin assays (amiodarone; propafenone; calcium-channel blockers such as verapamil, diltiazem, and nifedipine; quinidine; quinine; macrolide antibiotics, including clarithromycin, azithromycin, and erythromycin; tetracyclines; trimethoprim; or cyclosporine), ${ }^{1,11}$ serum electrolyte values (potassium, magnesium, and calcium), ${ }^{3,12}$ and baseline serum creatinine (i.e., the lowest recorded creatinine concentration during the admission). Acute kidney injury was defined according to modified RIFLE criteria: an increase in serum creatinine from baseline of at least $26.4 \mu \mathrm{mol} / \mathrm{L}$ or at least $150 \%-200 \%$ (1.5- to 2 -fold). ${ }^{13}$

Characteristics of the loading dose and subsequent serum concentrations were also collected (doses given, time of administration of each portion of loading dose, time of blood sample, and assay used). If samples for serum digoxin concentration were drawn beyond $6 \mathrm{~h}$ after administration of the last portion of the loading dose, the concentration was back-extrapolated to $6 \mathrm{~h}$ after the loading dose using the equation $\left.C_{\text {extrap }}=C_{\text {obs }} \mathrm{e}^{-k(6-t)}\right)$, where $C_{\text {extrap }}$ was the estimated back-extrapolated concentration, $C_{\text {obs }}$ was the observed (measured) concentration, $t$ was the time when $C_{\text {obs }}$ was measured (in terms of hours after the last portion of the digoxin loading dose was given), and estimated $k$ was dependent on $\mathrm{CrCl}^{1}{ }^{1}$ The institution's central laboratory measured serum digoxin using enzyme immunoassay (before April 3, 2011) or the LOCI (luminescent oxygen channelling) assay (on or after April 3, 2011). Evidence of toxicity was extracted from the medical record as any new documented clinical signs or symptoms of digoxin toxicity (anorexia, nausea, vomiting, weakness, visual disturbances, or sinus bradycardia $[<60 \mathrm{bpm}]$ ) within $48 \mathrm{~h}$ after the last portion of the loading dose for patients with post-loading serum digoxin concentration $2 \mathrm{nmol} / \mathrm{L}$ or above or any administration of antidote. Electrocardiograms obtained within $48 \mathrm{~h}$ of administration of the last portion of the loading dose for patients with a post-loading serum digoxin concentration $2 \mathrm{nmol} / \mathrm{L}$ or above were analyzed (by a single-blinded investigator [R.P.]) for evidence of toxicity (ventricular bigeminy, ventricular tachycardia, ventricular fibrillation, atrioventricular $[\mathrm{AV}]$ junctional escape rhythm, paroxysmal atrial tachycardia with AV block, atrial fibrillation with slow ventricular response [<60 bpm], Mobitz type 1 second-degree AV block). ${ }^{1,3,14,15}$

Current practice for digoxin loading and the proportion of patients with digoxin toxicity in each category of renal function are presented by descriptive statistics. Categorical data were compared between groups using Fisher's exact test. Dose $(\mu \mathrm{g} / \mathrm{kg})$ was compared between groups using analysis of variance and $\chi^{2}$ tests. The relationship between toxic digoxin concentrations (serum concentration $>2.6 \mathrm{nmol} / \mathrm{L}$ ) and renal function was analyzed by multivariable logistic regression with adjustment for dose and weight. Data were analyzed using SPSS, version 20.0 (IBM, Armonk, New York).

\section{RESULTS}

Retrospective screening of pharmacy records identified 1231 patients treated with digoxin between May 2008 and January 2012, of whom 142 met the initial inclusion criteria. Eleven patients were subsequently excluded: 6 patients were receiving continuous renal replacement therapy at the time of loading dose administration; 2 patients received hemodialysis between the time of loading dose administration and the time the sample was drawn for measurement of serum digoxin concentration; 2 patients weighed more than $120 \mathrm{~kg}$, with height not available; and for 1 patient, neither height nor weight was available. The final total sample size was 131 patients, 50 patients with $\mathrm{CrCl} 60 \mathrm{~mL} / \mathrm{min}$ or above, 50 patients with $\mathrm{CrCl}$ 30 to $59 \mathrm{~mL} / \mathrm{min}, 24$ patients with $\mathrm{CrCl} 15$ to $29 \mathrm{~mL} / \mathrm{min}$, and 7 patients with $\mathrm{CrCl}$ less than $15 \mathrm{~mL} / \mathrm{min}$. The latter 2 categories did not meet sample size targets, despite screening of 1231 patient records. Demographic data are presented in Table 1.

Loading doses were often higher than recommended by the manufacturer, ${ }^{1}$ and the timing of blood sampling for measurement of digoxin concentration after the loading dose was variable (Table 2 ). Although the mean digoxin loading dose was lower for patients with severe renal dysfunction $(\mathrm{CrCl}<15$ $\mathrm{mL} / \mathrm{min}$ ), similar weight-based loading doses were used across all other categories of renal function: 14 to $16 \mu \mathrm{g} / \mathrm{kg}$ lean body weight (Table 3). Toxic digoxin concentrations (> $2.6 \mathrm{nmol} / \mathrm{L}$ ) occurred more frequently among those who received a loading dose above $12 \mu \mathrm{g} / \mathrm{kg}(23 \%$ [22/95]) than among those who received $12 \mu \mathrm{g} / \mathrm{kg}$ or less $(14 \%$ [5/36]), but this difference was not statistically significant $(p=0.24)$.

The group with the greatest proportion having toxic digoxin concentrations ( $>2.6 \mathrm{nmol} / \mathrm{L}$ ) was that with $\mathrm{CrCl}$ of 15 to $29 \mathrm{~mL} / \mathrm{min}$ (38\% [9/24], unadjusted) (Table 3). The degree of renal failure (as categorized here) was predictive of toxic concentration after adjustment for dose and weight (odds ratio $2.60,95 \%$ confidence interval $1.55-4.39$ ).

When digoxin concentration was adjusted to $6 \mathrm{~h}$ after loading dose (i.e., $6 \mathrm{~h}$ after the last portion of the loading dose was administered) for each patient, 6 additional patients with toxic serum concentrations were identified (Table 3). Because of limited power in the categorization of patients with the most severe renal dysfunction, it was not possible to determine the degree of renal dysfunction at which there is an increased risk 
of toxic digoxin concentration after administration of the loading dose.

The medical records of all patients with digoxin concentrations of $2 \mathrm{nmol} / \mathrm{L}$ or above were reviewed for evidence of symptomatic toxicity. Such symptoms occurred in up to $20 \%$ of patients, with the highest incidence in the group with $\mathrm{CrCl}$

Table 1. Baseline Characteristics of 131 Patients

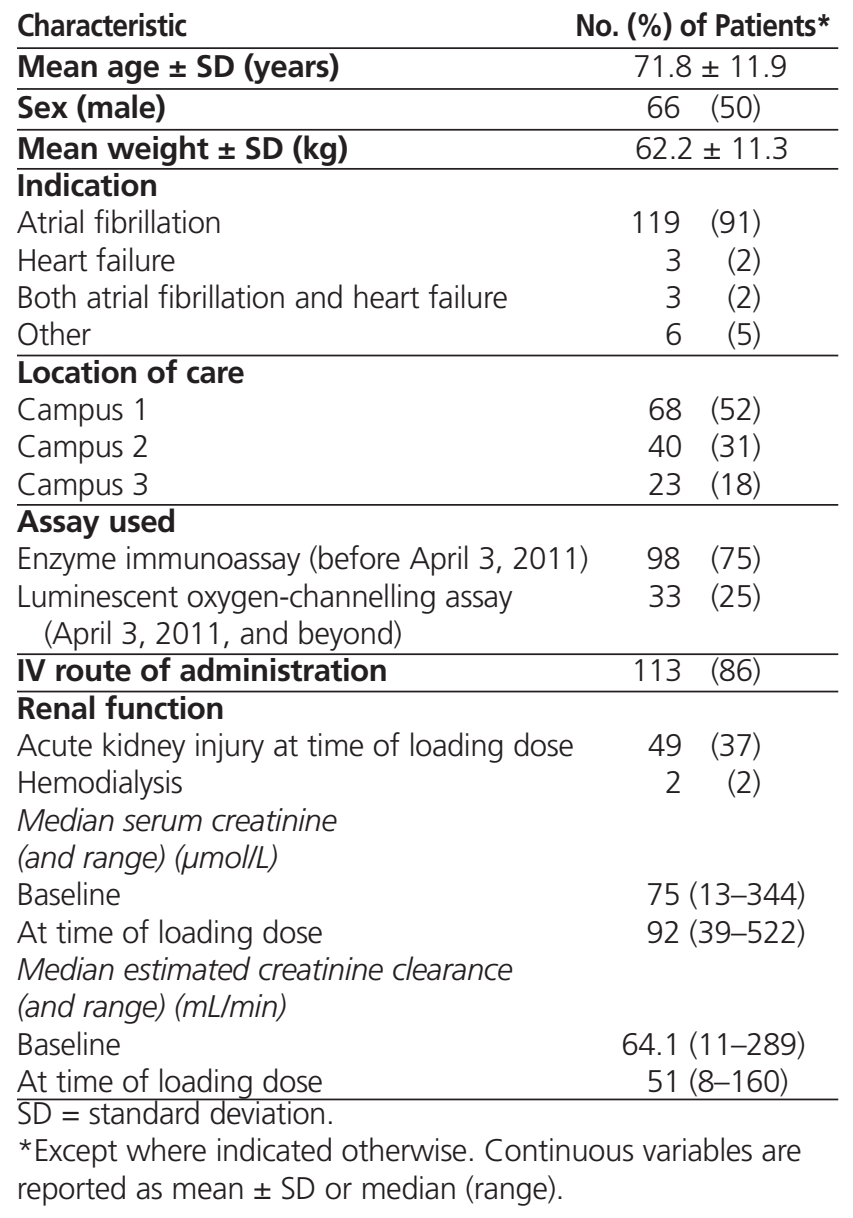

30 to $59 \mathrm{~mL} / \mathrm{min}$ (Table 3). Three patients with digoxin concentrations of $2 \mathrm{nmol} / \mathrm{L}$ or above experienced electrocardiographic changes that may be attributed to digoxin toxicity (2 patients with $\mathrm{CrCl} 30-59 \mathrm{~mL} / \mathrm{min}$ and 1 patient with $\mathrm{CrCl}$ $\geq 60 \mathrm{~mL} / \mathrm{min}$ ). No patients received the antidote, digoxin immune Fab fragments, for toxicity.

\section{DISCUSSION}

The results of this study suggest the importance of conservative dosing strategies when prescribing a loading dose of digoxin to patients with renal dysfunction. Worsening renal function, defined in terms of $\mathrm{CrCl}$, can lead to "toxic" serum digoxin concentration with the current loading dose strategy. These findings are consistent with the results of other studies that have investigated digoxin loading doses in patients with renal failure. ${ }^{715}$ Although this association has been previously described, the supporting data have been inconsistent. In addition, the lack of dose reduction, according to degree of renal dysfunction, observed at the authors' institution may reflect local clinical equipoise and/or clinicians' lack of awareness of this phenomenon. Loading doses were often higher than that recommended by the manufacturer, ${ }^{1}$ which may reflect a tendency to give a standard 1-mg loading dose of digoxin, regardless of ideal body weight or renal function. A nonsignificant trend toward greater "toxic" concentrations was observed in patients who received doses above the recommended dosage range (> $12 \mu \mathrm{g} / \mathrm{kg}$ ). To minimize the chance of toxicity, ideal body weight as well as renal function must be considered when calculating the loading dose.

Because of the smaller-than-expected number of patients meeting the inclusion criteria and limited resources, it was not feasible to achieve the desired sample size of 50 patients in the 2 groups of patients with the greatest renal dysfunction. Although we were unable to determine an appropriate loading dose for patients with increasing renal dysfunction, we did

Table 2. Digoxin Loading Dose and Characteristics of Serum Concentration Measurement*

\begin{tabular}{|c|c|c|c|c|c|}
\hline \multirow[b]{2}{*}{ Characteristic } & \multicolumn{5}{|c|}{ Creatinine Clearance Category (mL/min) } \\
\hline & $<15(n=7)$ & $15-29(n=24)$ & $30-59(n=50)$ & $\geq 60(n=50)$ & $p$ value \\
\hline $\begin{array}{l}\text { Mean estimated creatinine } \\
\text { clearance at time of loading } \\
\text { dose } \pm \text { SD }(\mathrm{mL} / \mathrm{min})\end{array}$ & $11.0 \pm 2.1$ & $21.4 \pm 3.5$ & $42.9 \pm 9.7$ & $83.8 \pm 21$ & NA \\
\hline IV route of administration, no. (\%) & $6(86)$ & $21(88)$ & $41(82)$ & $45(90)$ & $0.71 \dagger$ \\
\hline Use of LOCI assay, no. (\%) & $1(14)$ & $2(8)$ & $11(22)$ & $19(38)$ & $0.034 \dagger$ \\
\hline $\begin{array}{l}\text { Acute kidney injury at time of } \\
\text { loading dose, no. (\%) }\end{array}$ & $7(100)$ & $16(67)$ & $19(38)$ & $7(14)$ & NA \\
\hline $\begin{array}{l}\text { Mean time of concentration } \\
\text { measurement after loading } \\
\text { dose } \pm \text { SD }(h)\end{array}$ & $13.2 \pm 3.8$ & $15.2 \pm 6.1$ & $14.7 \pm 5.1$ & $13.7 \pm 5.7$ & $0.63 \ddagger$ \\
\hline
\end{tabular}




\section{CONCLUSIONS}

Patients with renal dysfunction were more likely than those without such dysfunction to experience toxic serum digoxin concentrations with current loading dose strategies. Patients with $\mathrm{CrCl}$ less than $60 \mathrm{~mL} / \mathrm{min}$ should receive adjusted weight-based doses to reduce the risk of toxicity (6-10 $\mu \mathrm{g} / \mathrm{kg}$ instead of $8-12 \mu \mathrm{g} / \mathrm{kg}$ ). Administration of standardized digoxin loading doses, irrespective of ideal body weight or renal function, was observed but is not recommended. Serum concentrations of digoxin reflecting the adequacy of the loading dose should be measured 6 to $8 \mathrm{~h}$ after the last portion of the loading dose is administered, as delayed measurements may not identify patients who are at risk of experiencing toxic effects. Future prospective trials are required to determine the clinical implications of these findings and to determine if further dose reductions are required for patients with severe renal dysfunction (i.e., $\mathrm{CrCl}<30 \mathrm{~mL} / \mathrm{min}$ ).

\section{References}

1. Lanoxin (digoxin) product monograph. Montreal (QC): Pharmascience Inc; July 2009.

2. Fuster V, Rydén LE, Cannom DS, Crijns HJ, Curtis AB, Ellenbogen KA, et al. ACC/AHA/ESC 2006 guidelines for the management of patients with atrial fibrillation-executive summary: a report of the American College of Cardiology/American Heart Association Task Force on Practice Guidelines and the European Society of Cardiology Committee for Practice Guidelines (Writing Committee to Revise the 2001 Guidelines for the Management of Patients With Atrial Fibrillation). Circulation. 2006;114(7):700-52.

3. The Ottawa Hospital laboratory information handbook. Ottawa $(\mathrm{ON})$ : The Ottawa Hospital, Department of Pathology and Laboratory Medicine; 2008. p. 42.

4. Cheng JW, Charland SL, Shaw LM, Kobrin S, Goldfarb S, Stanek EJ, et al. Is the volume of distribution of digoxin reduced in patients with renal dysfunction? Determining digoxin pharmacokinetics by fluorescence polarization immunoassay. Pharmacotherapy. 1997;17(3):584-90.

5. Aronson JK, Grahame-Smith DG. Altered distribution of digoxin in renal failure-a cause of digoxin toxicity? Br J Clin Pharmacol. 1976; 3(6): $1045-51$.

6. Paulson MF, Welling PG. Calculation of serum digoxin levels in patients with normal and impaired renal function. J Clin Pharmacol. 1976;16 (11-12):660-5.

7. Ohnhaus EE, Lenzinger HR, Galeazzi RL. Comparison of two different loading doses of digoxin in severe renal impairment. Eur J Clin Pharmacol. 1980;18(6):467-72.

8. Vöhringer HF, Rietbrock N. Digitalis therapy in renal failure with special regard to digitoxin. Int J Clin Pharmacol Ther Toxicol. 1981;19(4):175-84.

9. National Kidney Foundation. K/DOQI clinical practice guidelines for chronic kidney disease: evaluation, classification and stratification. $A m J$ Kidney Dis. 2002;39(2 Suppl 1):S1-266.

10. Cockcroft DW, Gault MH. Prediction of creatinine clearance from serum creatinine. Nephron. 1976;16(1):31-41.
11. Digoxin: serious drug interactions. Prescrire Int. 2010 Apr;19(106):68-70.

12. Lip GY, Metcalfe MJ, Dunn FG. Diagnosis and treatment of digoxin toxicity. Postgrad Med J. 1993;69(811):337-9.

13. Mehta RL, Kellum JA, Shah SV, Molitoris BA, Ronco C, Warnock DG, et al. Acute Kidney Injury Network: report of an initiative to improve outcomes in acute kidney injury. Crit Care. 2007;11(2):R31.

14. Digoxin. In: Bédard, M, Massicotte A, Prasad S, editors. Parenteral drug therapy manual. 32nd ed. Ottawa (ON): The Ottawa Hospital; 2011.

15. Marik PE, Fromm L. A case series of hospitalized patients with elevated digoxin levels. Am J Med. 1998;105(2):110-5.

16. Arnold JMO, Liu P, Demers C, Dorian P, Giannetti N, Haddad H, et al. Canadian Cardiovascular Society consensus conference recommendations on heart failure 2006: diagnosis and management. Can J Cardiol. 2006;22(1):23-45. Erratum in: Can J Cardiol. 2006;22(3):271.

17. Hunt SA, Abraham WT, Chin MH, Feldman AM, Francis GS, Ganiats TG, et al. ACC/AHA 2005 guideline update for the diagnosis and management of chronic heart failure in the adult: a report of the American College of Cardiology/American Heart Association Task Force on Practice Guidelines (Writing Committee to Update the 2001 Guidelines for the Evaluation and Management of Heart Failure). Circulation. 2005;112(12):e154-235.

18. Jusko WJ, Szefler SJ, Goldfarb AL. Pharmacokinetic design of digoxin dosage regimens in relation to renal function. J Clin Pharmacol. 1974; 14(10):525-35.

19. Doherty JE. Digitalis glycosides. Pharmacokinetics and their clinical implications. Ann Intern Med. 1973;79(2):229-38.

Nadia Pawlosky, , BSCPharm, ACPR, was, at the time of this study, a Pharmacy Resident at The Ottawa Hospital, Ottawa, Ontario. She is now is a Clinical Pharmacist, Royal Jubilee Hospital, Vancouver Island Health Authority, Victoria, British Columbia.

Erika MacDonald, BSCPharm, ACPR, is a Clinical Pharmacist, Department of Pharmacy, The Ottawa Hospital, Ottawa, Ontario.

Rakesh Patel, MD, PharmD, MSc(HRM), is Director of Adult Critical Care Medicine Training Program, The Ottawa Hospital, Ottawa, Ontario

Salmaan Kanji, BScPharm, PharmD, is a Clinical Pharmacy Specialist and Professional Practice Coordinator, The Ottawa Hospital, and an Associate Scientist, Ottawa Hospital Research Institute, Ottawa, Ontario.

Competing interests: None declared.

Address correspondence to:

Erika MacDonald

Department of Pharmacy

The Ottawa Hospital

501 Smyth Road

Ottawa ON K1H 8L6

e-mail: erimacdonald@toh.on.ca

\section{Acknowledgements}

We thank The Ottawa Hospital Pharmacy Research Committee for suggestions on design and conduct of the study. 